\title{
Medial medullary infarction with central sparing
}

Figure 1 Shaded areas indicate regions of decreased sensation

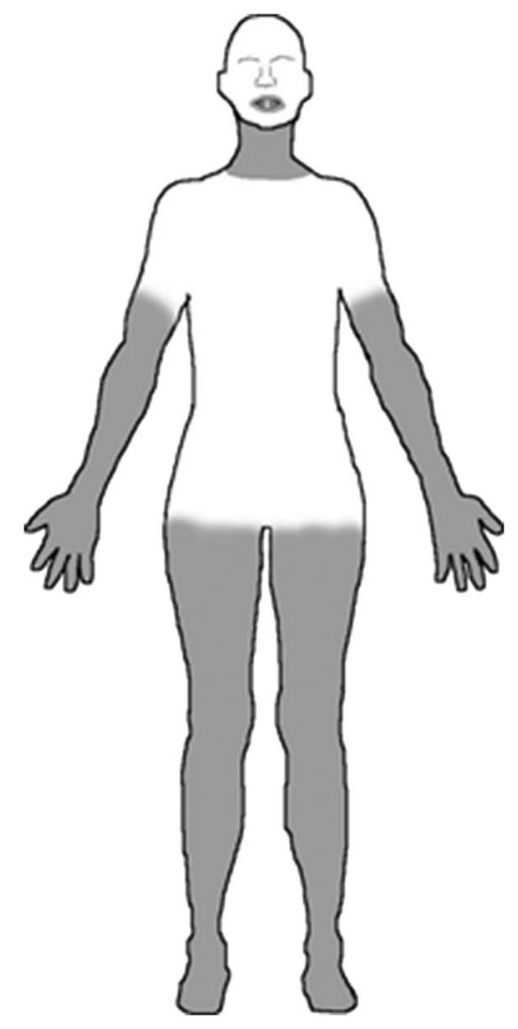

Figure 2 Brain MRI

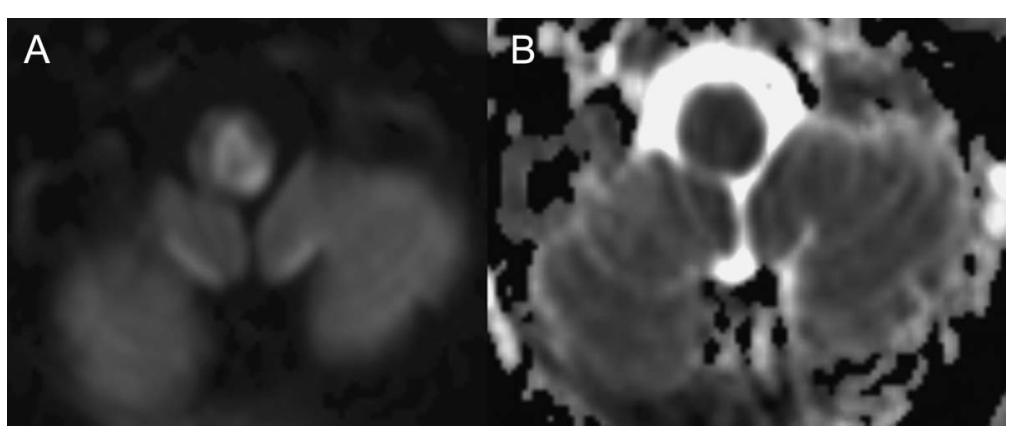

(A) Axial diffusion-weighted imaging and (B) apparent diffusion coefficient mapping show a ring-like area of ischemia involving the medial medulla with central sparing.

A 35-year-old woman had cardiac arrest requiring treatment with a left ventricular assist device. After regaining consciousness, examination revealed upbeating nystagmus, otherwise normal bulbar function, left arm dysmetria, and numbness periorally and in areas she described as "a turtleneck of numbness with a T-shirt of sensation" (figure 1). 
MRI showed diffusion restriction in a ring-like pattern in the medial medulla (figure 2), a probable embolic infarction given the clinical history. This correlated with the patient's preserved truncal sensation, since in the medullary portion of the medial lemniscus, truncal fibers are positioned centrally, between fibers from the lower extremities anteriorly and upper extremities posteriorly. ${ }^{1}$ In contrast to Dejerine syndrome, the hypoglossal nucleus was spared. Upbeating nystagmus and left arm dysmetria were consistent with involvement of the nucleus intercalatus ${ }^{2}$ and the cuneocerebellar tract, respectively.

Davis C. Ryman, MD, PhD, Yo-El S. Ju, MD

From Washington University School of Medicine, St Louis, MO.

Author contributions: Dr. Ryman: drafting/revising the manuscript for content, acquisition of data, analysis or interpretation of data. Dr. $\mathrm{Ju}$ : drafting/revising the manuscript for content, acquisition of data, analysis or interpretation of data.

Study funding: No targeted funding reported.

Disclosure: The authors report no disclosures relevant to the manuscript. Go to Neurology.org for full disclosures.

Correspondence to Dr. Ryman: rymand@neuro.wustl.edu

1. Kim JS, Koh JY, Lee JH. Medial medullary infarction with restricted sensory symptom. Eur Neurol 1998;39:174-177.

2. Saito T, Aizawa H, Sawada J, Katayama T, Hasebe N. Lesion of the nucleus intercalatus in primary position upbeat nystagmus. Arch Neurol 2010;67:1403-1404.

\section{NeuroImages Are Free at www.neurology.org!}

All Neurology ${ }^{\circledR}$ NeuroImages can now be freely accessed on the Neurology Web site. See them at www.neurology.org, where you can also sign up for journal email alerts and check out other online features, including the Resident \& Fellow section, Neurology: Clinical Practice, and the weekly Neurology Podcasts. 


\title{
Neurology
}

\author{
Medial medullary infarction with central sparing \\ Davis C. Ryman and Yo-El S. Ju \\ Neurology 2013;81;2054-2055 \\ DOI 10.1212/01.wnl.0000436939.70528.03
}

This information is current as of December 2, 2013

\section{Updated Information \& Services}

References

Subspecialty Collections

Permissions \& Licensing

Reprints including high resolution figures, can be found at: http://n.neurology.org/content/81/23/2054.full

This article cites 2 articles, 0 of which you can access for free at: http://n.neurology.org/content/81/23/2054.full\#ref-list-1

This article, along with others on similar topics, appears in the following collection(s):

Embolism

http://n.neurology.org/cgi/collection/embolism

Infarction

http://n.neurology.org/cgi/collection/infarction

MRI

http://n.neurology.org/cgi/collection/mri

Stroke in young adults

http://n.neurology.org/cgi/collection/stroke_in_young_adults

Information about reproducing this article in parts (figures,tables) or in its entirety can be found online at:

http://www.neurology.org/about/about_the_journal\#permissions

Information about ordering reprints can be found online:

http://n.neurology.org/subscribers/advertise

Neurology ${ }^{\circledR}$ is the official journal of the American Academy of Neurology. Published continuously since 1951 , it is now a weekly with 48 issues per year. Copyright @ 2013 American Academy of Neurology. All rights reserved. Print ISSN: 0028-3878. Online ISSN: 1526-632X.

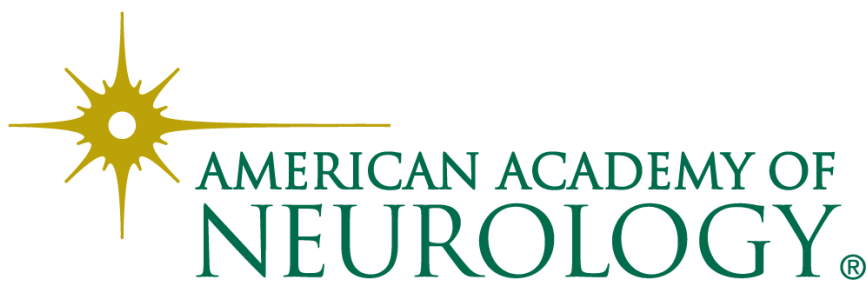

